\title{
Reassessment of the taxonomic structure of the diazotrophic genus Azoarcus sensu lato and description of three new genera and new species, Azovibrio restrictus gen. nov., sp. nov., Azospira oryzae gen. nov., sp. nov. and Azonexus fungiphilus gen. nov., sp. nov.
}

\author{
Barbara Reinhold-Hurek† and Thomas Hurek
}

Author for correspondence: Barbara Reinhold-Hurek. Tel: +49 421218 2370. Fax: +49 4212184042. e-mail: breinhold@uni-bremen.de

Max-Planck-Institut für terrestrische Mikrobiologie, Arbeitsgruppe Symbioseforschung, Karl-von-Frisch-Str., D-35043 Marburg, Germany

\begin{abstract}
The taxonomic structure of members of the genus Azoarcus sensu lato was reassessed in a polyphasic approach. Two species, Azoarcus communis and Azoarcus indigens, three unnamed species containing diazotrophs associated with Kallar grass roots (groups C, D) and a group of strains (E) isolated from fungi were analysed. They were compared by PAGE analyses of cellular proteins, genomic fingerprints, morphological and nutritional features to new isolates from rice roots. All strains within groups C, D and E containing 5-12 isolates showed group-specific cell and colony morphology and carbon source utilization patterns, with exception of the obligately microaerobic strain BS203, a member of group C. All strains, with this exception, also had almost indistinguishable electrophoretic protein patterns and genomic fingerprints generated with tDNA-directed primers, suggesting they belong to the same species. Phylogenetic analyses of almost complete $16 \mathrm{~S}$ rDNA sequences carried out with three different algorithms (neighbour-joining, maximum-likelihood, parsimony) revealed that Azoarcus sensu lato is not monophyletic. Groups C, D and $\mathrm{E}$ formed three distinct lineages located between the Azoarcus/Thauera and the Rhodocyclus clusters. Phylogenetic distances between groups C, D and $E$ were as large as between other genera (93-94\% sequence similarity). This suggested they have the rank of three different genera. Since it was possible to differentiate them from each other and other related bacteria by phenotypic features, three new genera with one type species each are proposed: Azovibrio restrictus gen. nov., sp. nov., Azospira oryzae gen. nov., sp. nov. and Azonexus fungiphilus gen. nov., sp. nov.
\end{abstract}

Keywords: Azoarcus, nitrogen fixation, rice, phylogeny

\section{INTRODUCTION}

A genus of aerobic Proteobacteria, Azoarcus, was originally described with two valid diazotrophic species, Azoarcus communis and Azoarcus indigens (Reinhold-Hurek et al., 1993). Another diazotrophic strain (BH72), which clustered with Azoarcus spp. in rRNA-DNA homology studies (Reinhold-Hurek et

\footnotetext{
† Present address: University of Bremen, Faculty of Biology and Chemistry, Institute of General Microbiology, Postfach 3304 40, D-28334 Bremen, Germany.
}

al., 1993) and 16S rRNA sequence analyses (Hurek et al., 1993), was distinct at the species level according to DNA-DNA homology studies, but has not been named yet (Reinhold-Hurek et al., 1993). Two other types of diazotrophs, group C and group D, were also distinct at the species level and clearly located on the Azoarcus rRNA branch according to rRNA-DNA hybridization studies, albeit at lower $T_{\mathrm{m}(\mathrm{e})}$ values $\left(71 \cdot 4-71 \cdot 6{ }^{\circ} \mathrm{C}\right)$. As they contained too few strains and their phenotypic features were not sufficiently discriminating, these species were not named but included in the genus Azoarcus sensu lato (Reinhold-Hurek et 
al., 1993). All strains included in the original description, except for two, shared a similar habitat: the interior of roots or stems of Kallar grass, a pioneer plant grown on a salt-affected field in the Punjab of Pakistan (Reinhold et al., 1986; Reinhold-Hurek et al., 1993). These bacteria are, in common with other diazotrophic endophytes of grasses, tightly associated with plants and have not been isolated from soil as yet (Boddey, 1995; Reinhold-Hurek \& Hurek, 1998). In recent surveys, additional strains of plant-associated Azoarcus species have been cultivated from other sources, such as roots of several rice species (Engelhard et al., 2000) and resting stages of a plant-associated basidiomycete (Hurek et al., 1997). This fungus also harboured a new bacterial lineage, Azoarcus sp. group E (Hurek et al., 1997). Availability of additional strains allowed us to reassess the taxonomic structure of members of the genus Azoarcus sensu lato in a polyphasic approach, based on phylogenetic analysis of $16 \mathrm{~S}$ rDNA sequences, genomic fingerprints and phenotypic characteristics.

Knowledge about the diversity within Azoarcus sensu stricto was increased by the description of several new species with different ecological and physiological features. Azoarcus tolulyticus (Fries et al., 1994) and Azoarcus evansii (Anders et al., 1995), which have been isolated from soils or sediments, are capable of degrading aromatic hydrocarbons. Azoarcus anaerobicus (Springer et al., 1998), which is a respiratory but strictly anaerobic bacterium, and strains degrading ethylbenzene (Rabus \& Widdel, 1995) or cyclohexane1,2-diol (Harder, 1997) were recently suggested to belong to the genus Azoarcus.

The availability of 16S rDNA sequences of Azoarcus spp. and related groups now allow a revision of the phylogenetic relationships within this branch. Analyses based on a 16S rDNA fragment (446 bp) have placed the species of Azoarcus sensu lato in one lineage (Hurek \& Reinhold-Hurek, 1995). However, a recent analysis based on almost complete sequences suggested that only Azoarcus sensu stricto is monophyletic, whereas the other species represent different lineages and thus different genera (Hurek et al., 1997). As a result of our polyphasic taxonomic studies, we here suggest splitting Azoarcus sensu lato into four genera, Azoarcus (previously sensu stricto), Azovibrio gen. nov., Azonexus gen. nov. and Azospira gen. nov.

\section{METHODS}

Bacterial strains. The strains used in this study are listed in Table 1. Reference strains of Azoarcus tolulyticus (Td-1) and Azoarcus evansii $\left(\mathrm{KB} 740^{\mathrm{T}}\right)$ were kindly provided by J. M. Tiedje and G. Fuchs, respectively. Type cultures of the new species were deposited at the BCCM/LMG culture collection, Belgium.

Media and growth conditions. Unless stated otherwise, cells were grown at $37^{\circ} \mathrm{C}$. For mass culture and maintenance, cells were grown on VM ethanol medium which consisted of $\left(1^{-1}\right): \mathrm{K}_{2} \mathrm{HPO}_{4}, 0.6 \mathrm{~g} ; \mathrm{KH}_{2} \mathrm{PO}_{4}, 0.4 \mathrm{~g} ; \mathrm{NH}_{4} \mathrm{Cl}, 0.5 \mathrm{~g}$;
$\mathrm{MgSO}_{4} .7 \mathrm{H}_{2} \mathrm{O}, 0 \cdot 2 \mathrm{~g} ; \mathrm{NaCl}, 1 \cdot 1 \mathrm{~g} ; \mathrm{CaCl}_{2} .2 \mathrm{H}_{2} \mathrm{O}, 0.026 \mathrm{~g}$; $\mathrm{MnSO}_{4} . \mathrm{H}_{2} \mathrm{O}, 0.01 \mathrm{~g} ; \mathrm{Na}_{2} \mathrm{MoO}_{4} .2 \mathrm{H}_{2} \mathrm{O}, 0.002 \mathrm{~g}$; $\mathrm{Fe}(\mathrm{III})-$ EDTA, $0.066 \mathrm{~g}$; yeast extract, $1 \mathrm{~g}$; Bacto-Tryptone, $3 \mathrm{~g}$; pH $6 \cdot 8$; ethanol, $6 \mathrm{ml}$, sterilized by filtration. For determination of colony morphology, malic acid medium supplemented with Congo red (Cacarez, 1982) was used. Cells were also grown on semi-solid N-free SM medium (Reinhold et al., 1986) for nitrogen fixation, or on SM medium with combined nitrogen (Reinhold et al., 1985), both supplemented with $1 \mathrm{ml}$ of a mixture of vitamins $1^{-1}$ (Hurek et al., 1995).

Morphological and physiological tests. Cell dimensions and morphology were determined by phase-contrast microscopy after growth on $\mathrm{N}_{2}$ and on SM medium with combined nitrogen. Microscopic images were recorded with a 3Chip RGB Colour Camera (Hamamatsu Photonic Systems). Electron micrographs were taken from cells negatively stained with phosphotungstate. Colony morphology was observed after growth on VM ethanol medium and Congo red agar. Salt and temperature tolerance were monitored in liquid VM ethanol medium inoculated with $1 \%(\mathrm{v} / \mathrm{v})$ preculture, after $1 \mathrm{~d}$ incubation. Requirements for growth factors or tests for carbon source utilization were carried out in liquid SM medium as described previously (Hurek et al., 1997). Potassium malate was replaced by the respective neutralized carbon source. Biotype 100 strips with medium 2 (bioMérieux) supplemented with the vitamin mixture $\left(1 \mathrm{ml} \mathrm{l}^{-1}\right)$ were applied to determine nutritional profiles. The inoculum was grown for $2 \mathrm{~d}$ on VM ethanol agar plates at $37^{\circ} \mathrm{C}$ and suspended in $0.9 \%(\mathrm{w} / \mathrm{v}) \mathrm{NaCl}$ solution. Strips were inoculated according to manufacturer's instructions. Growth was recorded after 1, 2, 4 and $7 \mathrm{~d}$ incubation at $30{ }^{\circ} \mathrm{C}$. The values obtained on day 4 are listed in Table 2 since recordings on day 7 did not differ from day 4 .

Electrophoretic patterns of SDS-soluble proteins. Cells were grown on VM ethanol agar plates (diam. $14 \mathrm{~cm}$ ) for $36 \mathrm{~h}$ at $30{ }^{\circ} \mathrm{C}$ after inoculation with a preculture grown overnight in the same liquid medium, washed and suspended in $0.9 \%$ (w/v) $\mathrm{NaCl}$ solution. Extracts of SDS-soluble proteins were prepared from whole cells as described by Kiredjian et al. (1986). Proteins were separated by SDS-PAGE on $12.5 \%(\mathrm{w} / \mathrm{v})$ polyacrylamide gels $(30: 1, \mathrm{w} / \mathrm{w}$, acrylamide/ bisacrylamide) and stained with Coomassie brilliant blue R250.

DNA preparation. DNA was extracted from 1-2 $\mathrm{ml}$ of wellgrown liquid cultures as described previously (Hurek et al., 1993).

Genomic fingerprints by tDNA-PCR. PCR with tRNA-gene directed primers MS9 and MS10, which were 5'-labelled with the fluorescent dye CY-5, and analysis of amplification products on an automated sequencer (ALFexpress; Pharmacia) were carried out according to Hurek et al. (1997).

Phylogenetic analysis of 16S rRNA genes. Aligned sequences of 16S rRNA genes were loaded from the Ribosomal Database Project (www.cme.msu.edu/RDP/analyses.html) and put into GeneDoc software version 2.4.0 (www.cris. $\mathrm{com} / \sim$ ketchup/genedoc.shtml). Tree inference on 1338 sequence positions was carried out using the neighbourjoining algorithm of TREECON version $1.3 \mathrm{~b}$ (Van de Peer \& de Wachter, 1994) with a Jukes-Cantor correction distance matrix, using the complete deletion option. Alternatively, an unrooted maximum-likelihood quartet-puzzling tree was inferred using 10000 puzzling steps in the Tamura-Nei model (Tamura \& Nei, 1993). Parsimony analysis was done with the DNAPARS program of the PHYLIP 3.5c package 
Table 1. Strains used

\begin{tabular}{|c|c|c|c|}
\hline Taxon & Strain & Other designation & Source of isolation and/or reference \\
\hline Azoarcus tolulyticus & Td-1 & & $\begin{array}{l}\text { Petroleum-contaminated soil, Western Washington (Fries et al., } \\
\text { 1994) }\end{array}$ \\
\hline Azoarcus evansii & $\mathrm{KB} 740^{\mathrm{T}}$ & DSM $6898^{\mathrm{T}}$ & Creek sediment, USA (Anders et al., 1995) \\
\hline \multirow[t]{5}{*}{ Azoarcus indigens } & VB32 $2^{\mathrm{T}}$ & LMG $9092^{\mathrm{T}}$ & $\begin{array}{l}\text { Surface-sterilized (SS) stem bases of Kallar grass, Pakistan } \\
\text { (Reinhold-Hurek et al., 1993) }\end{array}$ \\
\hline & VW35a & & SS roots of Kallar grass, Pakistan (Reinhold-Hurek et al., 1993) \\
\hline & VW34c & & SS roots of Kallar grass, Pakistan (Reinhold-Hurek et al., 1993) \\
\hline & BS2-10 & & Fungal sclerotium from rice field, Pakistan (Hurek et al., 1997) \\
\hline & OSP14-2 & & $\begin{array}{l}\text { SS roots of Oryza sativa, Khumaltar, Nepal (Engelhard et al., } \\
2000)\end{array}$ \\
\hline \multirow[t]{3}{*}{ Azoarcus communis } & SWub3 ${ }^{\mathrm{T}}$ & LMG $9095^{\mathrm{T}}$ & $\begin{array}{l}\text { Root piece of Kallar grass, Pakistan (Reinhold-Hurek et al., } \\
\text { 1993) }\end{array}$ \\
\hline & $\mathrm{S} 2$ & LMG 5514, BPD2 & Refinery oily sludge, France (Laguerre et al., 1987) \\
\hline & LFN91 & & Root piece of Kallar grass, Pakistan (Engelhard et al., 2000) \\
\hline Azoarcus sp. & $\mathrm{BH} 72$ & & SS roots of Kallar grass, Pakistan (Reinhold-Hurek et al., 1993) \\
\hline \multirow{5}{*}{$\begin{array}{l}\text { Azovibrio restrictus } \\
\text { (formerly Azoarcus sp. } \\
\text { group C) }\end{array}$} & $\mathrm{S} 5 \mathrm{~b} 2^{\mathrm{T}}$ & LMG $9099^{\mathrm{T}}$ & SS roots of Kallar grass, Pakistan (Reinhold-Hurek et al., 1993) \\
\hline & S5b1 & & SS roots of Kallar grass, Pakistan (Reinhold-Hurek et al., 1993) \\
\hline & SSa3 & & SS roots of Kallar grass, Pakistan (Reinhold-Hurek et al., 1993) \\
\hline & BS1-14 & & Fungal sclerotium from rice soil, Pakistan (Hurek et al., 1997) \\
\hline & OSB2-4 & & $\begin{array}{l}\text { SS roots of Oryza sativa, Bulbuhle, Nepal (Engelhard et al., } \\
2000 \text { ) }\end{array}$ \\
\hline \multirow{12}{*}{$\begin{array}{l}\text { Azovibrio sp. } \\
\text { Azospira oryzae } \\
\text { (formerly Azoarcus sp. } \\
\text { group D) }\end{array}$} & BS20-3 & & Fungal sclerotium from rice soil, Pakistan (Hurek et al., 1997) \\
\hline & $6 \mathrm{a} 3^{\mathrm{T}}$ & LMG $9096^{\mathrm{T}}$ & $\begin{array}{l}\text { SS roots from Kallar grass, Pakistan (Reinhold-Hurek et al., } \\
\text { 1993) }\end{array}$ \\
\hline & $6 \mathrm{a} 2$ & & $\begin{array}{l}\text { SS roots from Kallar grass, Pakistan (Reinhold-Hurek et al., } \\
\text { 1993) }\end{array}$ \\
\hline & BS2-3 & & Fungal sclerotium from rice soil, Pakistan (Hurek et al., 1997) \\
\hline & OM8A-5 & & $\begin{array}{l}\text { SS roots of Oryza officinalis, Kapilavastu, Nepal (Engelhard et } \\
\text { al., 2000) }\end{array}$ \\
\hline & OO80-5 & & SS roots of Oryza officinalis, Nepal (Engelhard et al., 2000) \\
\hline & OMP5-6 & & $\begin{array}{l}\text { SS roots of Oryza minuta, Pangil, Philippines (Engelhard et al., } \\
2000)\end{array}$ \\
\hline & OSB4-5 & & $\begin{array}{l}\text { SS roots of Oryza sativa, Bulbuhle, Nepal (Engelhard et al., } \\
2000)\end{array}$ \\
\hline & OSL52-5 & & SS roots of Oryza sativa, Laha, Nepal (Engelhard et al., 2000) \\
\hline & OSP16-4S & & $\begin{array}{l}\text { SS roots of Oryza sativa, Khumaltar, Nepal (Engelhard et al., } \\
\text { 2000) }\end{array}$ \\
\hline & OSP39 & & $\begin{array}{l}\text { Root pieces of Oryza sativa, Khumaltar, Nepal (Engelhard et } \\
\text { al., 2000) }\end{array}$ \\
\hline & OSC17 & & Root pieces, Oryza sativa, Italy (Engelhard et al., 2000) \\
\hline \multirow{5}{*}{$\begin{array}{l}\text { Azonexus fungiphilus } \\
\text { (formerly Azoarcus sp. } \\
\text { group E) }\end{array}$} & BS5-8 ${ }^{\mathrm{T}}$ & LMG $19178^{\mathrm{T}}$ & Fungal sclerotium from rice soil, Pakistan (Hurek et al., 1997) \\
\hline & BS19-2 & & Fungal sclerotium from rice soil, Pakistan (Hurek et al., 1997) \\
\hline & BS19-5 & & Fungal sclerotium from rice soil, Pakistan (Hurek et al., 1997) \\
\hline & BS19-7 & & Fungal sclerotium from rice soil, Pakistan (Hurek et al., 1997) \\
\hline & BS22-6 & & Fungal sclerotium from rice soil, Pakistan (Hurek et al., 1997) \\
\hline
\end{tabular}

(Felsenstein, 1993). Bootstrap values were calculated from 100 pseudoreplicates generated by the SEQBOOT program.

\section{RESULTS AND DISCUSSION}

\section{Comparison of electrophoretic protein patterns}

To determine interstrain variations within the different groups of Azoarcus sensu lato, patterns of SDS-soluble proteins were compared by SDS-PAGE (Fig. 1). In each group, isolates from different sources, i.e. a representative Azoarcus strain originating from Kallar grass (Reinhold-Hurek et al., 1993) and novel isolates from rice roots (Engelhard et al., 2000 or fungal sclerotia (Hurek et al., 1997) were analysed. They had almost indistinguishable protein patterns within Azoarcus sp. group C (lanes 1-4) and group D (lanes 5-14), except for strain BS20-3 (lane 4), which differed substantially from other members of group C. Within 
Table 2. Characteristics of strains of the genera Azoarcus, Azovibrio, Azospira and Azonexus

Data from this study and from Reinhold-Hurek et al. (1993), Hurek \& Reinhold-Hurek (1995); Hurek et al. (1997), Anders et al. (1995), Zhou et al. (1995), Rhee et al. (1997) and Engelhard et al. (2000). +, Positive for all strains; -, negative for all strains; w, weak reaction for all strains; $r$, rare; $d, 11-89 \%$ of strains are positive; numbers, number of strains giving positive reactions; $v$, strain instability; ND, not determined. All strains have the following features: cells are straight to curved rods; growth on $\mathrm{N}_{2}$ under microaerobic conditions; oxidase-positive; catalase-positive (not determined for BS20-3); no growth in the presence of 5\% $\mathrm{NaCl}$ and no growth-rate increase when $\mathrm{NaCl}$ is added to medium; denitrification (not determined for Azonexus sp.); no spore formation; no starch hydrolysis (not determined for Azoarcus evansii).

\begin{tabular}{|c|c|c|c|c|c|c|c|c|c|}
\hline Characteristic & $\begin{array}{l}\text { Azoarcus indigens } \\
\quad(n=5)\end{array}$ & $\begin{array}{c}\text { Azoarcus } \\
\text { communis } \\
\quad(n=3)\end{array}$ & $\begin{array}{c}\text { Azoarcus sp. } \\
\quad \text { BH72 } \\
(n=1)\end{array}$ & $\begin{array}{l}\text { Azoarcus } \\
\text { tolulyticus* }\end{array}$ & $\begin{array}{c}\text { Azoarcus } \\
\text { evansii }^{*}\end{array}$ & $\begin{array}{c}\text { Azovibrio } \\
\text { restrictus } \\
\quad(n=5)\end{array}$ & $\begin{array}{c}\text { Azovibrio sp. } \\
\text { BS20-3 } \\
(n=1)\end{array}$ & $\begin{array}{c}\text { Azospira } \\
\text { oryzae } \\
(n=12)\end{array}$ & $\begin{array}{l}\text { Azonexus } \\
\text { fungiphilus } \\
\quad(n=5)\end{array}$ \\
\hline Cell width $(\mu \mathrm{m})$ & $0 \cdot 5-0 \cdot 7$ & $0 \cdot 8-1 \cdot 0$ & $0 \cdot 6-0 \cdot 8$ & $0 \cdot 8-1 \cdot 0^{*}$ & $0 \cdot 4-0 \cdot 8$ & $0 \cdot 6-0 \cdot 8$ & $0 \cdot 6-0 \cdot 8$ & $0 \cdot 4-0 \cdot 6$ & $0 \cdot 6-0 \cdot 8$ \\
\hline Cell length $(\mu \mathrm{m})$ & $2 \cdot 0-4 \cdot 0$ & $1 \cdot 5-3 \cdot 0$ & $1 \cdot 5-4 \cdot 0$ & $1 \cdot 4-2 \cdot 8$ & $1 \cdot 5-3 \cdot 0$ & $1 \cdot 5-3 \cdot 5$ & $1 \cdot 5-3 \cdot 5$ & $1 \cdot 1-2 \cdot 5$ & $1 \cdot 5-4 \cdot 0$ \\
\hline Elongated cells in stationary cultures & $\mathrm{r}$ & $\mathrm{r}$ & $\mathrm{r}$ & - & - & $\mathrm{r}$ & ND & $\mathrm{r}$ & + \\
\hline Colony diameter $(\mathrm{mm} ; \mathrm{VM} / \mathrm{CR}) \dagger$ & $2-3$ & $2-4$ & $2-3 / 1$ & $1-1 \cdot 5^{*}$ & $0 \cdot 2-0 \cdot 7^{*}$ & $1 \cdot 5-2 / 1$ & Negligible & $1-2$ & $1-2 / 0 \cdot 7$ \\
\hline Colony colour $(\mathrm{VM}) \dagger$ & $\begin{array}{l}\text { Opaque } \\
\text { yellowish }\end{array}$ & $\begin{array}{l}\text { Translucent } \\
\text { yellowish }\end{array}$ & $\begin{array}{l}\text { Translucent } \\
\text { yellowish }\end{array}$ & $\begin{array}{l}\text { Opaque } \\
\text { yellowish* }\end{array}$ & $\begin{array}{l}\text { Translucent } \\
\text { beige* }\end{array}$ & Opaque beige & Negligible & $\begin{array}{l}\text { Translucent } \\
\text { pink-salmon }\end{array}$ & Opaque ochreous \\
\hline Colony colour $(\mathrm{CR}) \dagger$ & $\begin{array}{l}\text { Whiteish pink, } \\
\text { white margin }\end{array}$ & $\begin{array}{l}\text { Whiteish pink, } \\
\text { pink centre }\end{array}$ & Orange-red & Orange-red & Orange-red & Orange-red & Negligible & $\begin{array}{l}\text { Translucent } \\
\text { orange }\end{array}$ & Dark red \\
\hline Colony surface & Rough & Smooth & Shiny & Shiny & Shiny & Shiny & & Shiny & Shiny \\
\hline Growth at $40^{\circ} \mathrm{C}$ & + & + & + & $-^{*}$ & $-^{*}$ & $4 \$$ & ND & + & + \\
\hline Growth in presence of $2 \% \mathrm{NaCl}$ & w & 1 & w & $\mathrm{d} \S$ & ND & $\mathrm{w}$ & ND & - & + \\
\hline Requirement for $p$-aminobenzoic acid & + & - & - & - & - & - & - & - & - \\
\hline Requirement for cobalamine & - & $1 \|$ & - & - & - & - & + & $8 \|$ & + \\
\hline Oxidation/fermentation of glucose & - & - & - & $\mathrm{ND}$ & $+\bullet$ & - & - & - & - \\
\hline \multicolumn{10}{|l|}{ Sole carbon sources for growth:\# } \\
\hline n-Butylamine, 3-hydroxybenzoate & + & + & + & $+*$ & $+*$ & - & - & - & - \\
\hline Benzylamine & $1^{\mathrm{a}}$ & $\mathrm{v}$ & + & $+^{*}$ & $+^{*}$ & - & - & - & - \\
\hline Phenylacetate & + & + & + & $-*$ & $+*$ & - & - & - & - \\
\hline Benzoate & $1^{\mathrm{b}}$ & $1^{\mathrm{c}}$ & + & + & + & - & - & - & - \\
\hline L-Phenylalanine & + & + & - & $+^{*}$ & + & - & - & - & - \\
\hline $\mathrm{D}(+)$-Malate & + & + & + & $+^{*}$ & $-*$ & $4^{d}$ & - & - & - \\
\hline L-Alanine & $2^{\mathrm{e}}$ & + & + & $+*$ & $+*$ & $2^{\mathrm{e}}$ & + & - & - \\
\hline 2-Oxoglutarate & + & + & + & $-{ }^{*}$ & $+^{*}$ & - & - & + & + \\
\hline D-Tartrate & + & $1^{\mathrm{e}}$ & + & $-{ }^{*}$ & + & - & - & + & - \\
\hline$n$-Caproate & - & + & + & $-^{*}$ & $-{ }^{*}$ & - & - & + & - \\
\hline Propionate & + & + & + & $-{ }^{*}$ & + & + & + & + & - \\
\hline Isovalerate & - & + & + & $+^{*}$ & $+^{*}$ & - & + & + & - \\
\hline L-Proline & - & - & - & $+^{*}$ & + & - & - & - & + \\
\hline Malonate & - & - & - & - & - & - & - & - & $1^{\mathrm{f}}$ \\
\hline $\mathrm{D}(+)$-Glucose, maltose & - & - & - & + & $1^{\mathrm{g}}$ & - & - & - & - \\
\hline $\mathrm{D}(+)$-Fructose & - & - & - & + & $+\bullet$ & - & - & - & - \\
\hline $\begin{array}{l}\mathrm{D}(+) \text {-Galactose, sucrose, } \\
\text { maltotriose, palatinose, } \mathrm{D}(+) \text { - } \\
\text { melezitose, } \\
\text { maltitol, } \mathrm{D}(+) \text {-turanose, } \\
\text { trans-aconitate }\end{array}$ & - & - & - & $+^{*}$ & $+*$ & - & - & - & - \\
\hline DL-Glycerate & $3^{\mathrm{h}}$ & - & - & $+^{*}$ & $+*$ & - & - & - & - \\
\hline Toluene (denitrifying) & - & - & - & + & ND & - & - & - & - \\
\hline $\begin{array}{l}\text { Protocatechuate, } \\
\text { 4-hydroxybenzoate, L-mandelate }\end{array}$ & + & + & + & $-*$ & $-*$ & - & - & - & - \\
\hline$m$-Coumarate & $1^{i}$ & + & + & $-{ }^{*}$ & $-{ }^{*}$ & - & - & - & - \\
\hline Tryptamine & + & $\mathrm{v}$ & + & $-{ }^{*}$ & $-{ }^{*}$ & - & - & - & - \\
\hline Gentisate & + & + & + & $-{ }^{*}$ & + & - & - & - & - \\
\hline $\begin{array}{l}\mathrm{L}(+) \text {-Tartrate, meso-tartrate } \\
\text { and betain* }\end{array}$ & - & - & - & - & $+\uparrow$ & - & - & - & - \\
\hline p-Aminobenzoate & + & - & - & $-{ }^{*}$ & + & - & - & - & - \\
\hline Itaconate & + & - & - & $-{ }^{*}$ & $-{ }^{*}$ & - & - & - & - \\
\hline Glutarate & - & + & + & $+^{*}$ & $+^{*}$ & - & - & - & - \\
\hline D-Mandelate & + & + & - & $-{ }^{*}$ & $-{ }^{*}$ & - & - & - & - \\
\hline Citrate & - & + & - & - & - & - & - & - & - \\
\hline Glycerol, D-alanine & - & $1^{\mathrm{c}}$ & - & - & - & - & - & - & - \\
\hline$(-)$-Quinate & - & $1^{\mathrm{c}}$ & - & $+^{*}$ & - & - & - & - & - \\
\hline Isobutyrate & - & + & + & $+^{*}$ & $+^{*}$ & $1^{\mathrm{j}}$ & + & $\mathrm{v}$ & - \\
\hline L-Aspartate & + & $\mathrm{v}$ & + & $+^{*}$ & + & + & - & + & + \\
\hline 3-Hydroxybutyrate & + & + & + & $+^{*}$ & $+^{*}$ & - & + & + & + \\
\hline
\end{tabular}

* Marked characters were determined in this study for Azoarcus tolulyticus Td-1 or Azoarcus evansii $\mathrm{KB}^{2} 40^{\mathrm{T}}$.

$\dagger$ Growth on VM ethanol agar (VM) or Congo red agar (CR) at $37^{\circ} \mathrm{C}$ for $4 \mathrm{~d}$.

$\$$ Positive for Azovibrio restrictus except strain OSB2-4.

$\S$ Positive in Azoarcus tolulyticus except strain Tol-4 ${ }^{\mathrm{T}}$, and Td-1 in this study.

$\|$ Requirement for Azoarcus communis LFN91 and all strains of Azospira oryzae except 6a3 ${ }^{\mathrm{T}}$, 6a2, 5c1, and OO80-5.

- Not tested for Azoarcus evansii pF6. 


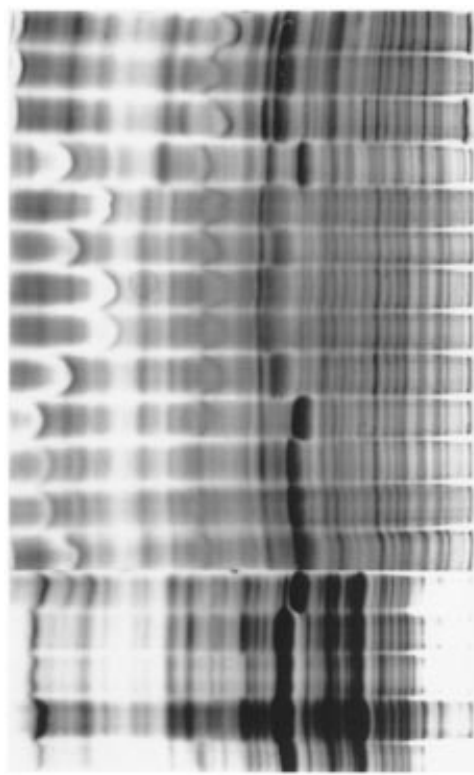

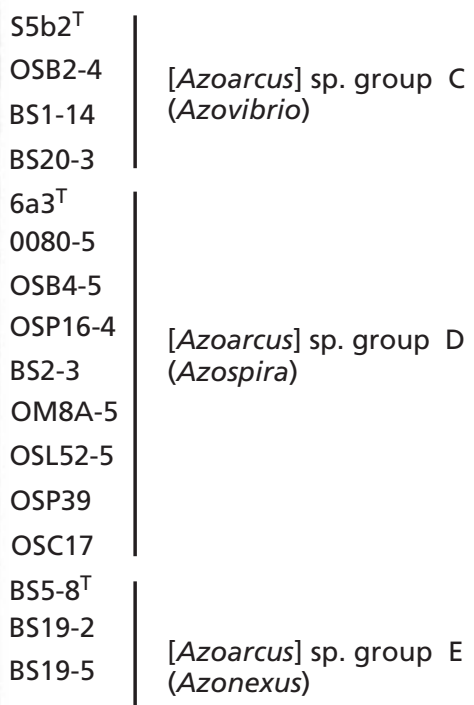

BS19-7 BS22-6
Fig. 1. Normalized SDS-PAGE patterns of Azoarcus sensu lato strains group C, D and E, originating from the root interior of Kallar grass or rice, or from fungal sclerotia. group D, strains OM8A-5, OSL52-5, OSP39 and OSC17 formed a subgroup by differing in one major protein band from the others. All strains of Azoarcus sp. group E, which had been isolated from fungal sclerotia (Hurek et al., 1997) had nearly identical protein patterns (lanes 15-19) except for strain BS5-8 ${ }^{\mathrm{T}}$ which differed in one major band. Almost indistinguishable protein patterns indicate a high degree of overall genomic similarity (Kersters, 1985) which suggested that the respective strains within a group belonged to the same species, except for isolate BS20-3.

\section{Genomic fingerprints by tDNA-PCR}

For analysis of the genotypic variations within groups of Azoarcus sensu lato, PCR-based genomic fingerprints were compared. Primers to tRNA genes applied at low stringency were previously shown to amplify bands of different sizes, most likely clusters of tRNA genes (Hurek et al., 1997). The tDNA-PCR profiles were shown to correlate well with the species affiliation in Azoarcus spp., except for group $\mathrm{E}$ in which only a single band was amplified (Hurek et al., 1997). Fig. 2 shows genomic fingerprints generated by tDNA PCR for different strains of Azoarcus indigens (lanes 1-5) as well as Azoarcus sp. group C and group D (lanes 11-20). Most fingerprint profiles were group-specific. Strains of fungal or rice origin showed patterns almost identical to Kallar grass strains within a given group (lanes $4 / 2$ or $5 / 3$, respectively). Within group $C$, all strains, including BS20-3, shared three major bands (lanes 6-10); however, some variation occurred in minor bands. Banding patterns within group D were very homogeneous, with five major bands which almost all strains had in common (lanes 11-20). Strains OM8A-5, OSL52-5 and OSP39, which in protein patterns showed some deviation from other members of the group, were identical in fingerprints to, for example OO80-5 and OSP16-4, indicating high genomic similarities. Thus, PCR-based fingerprints confirmed that members within group $\mathrm{C}$ or $\mathrm{D}$ of Azoarcus sensu lato were likely to belong to the same species.

\section{Phylogenetic analyses of 16S rDNA sequences}

The 16S rRNA genes of Azoarcus spp. and representative genera of the $\beta$-subclass of the Proteobacteria were subjected to phylogenetic analysis using different methods. As a result of these and other studies, we propose three new genera (Azovibrio, Azospira and

\# All strains grow on L-malate, DL-lactate, succinate, fumarate, ethanol, acetate (except for Azoarcus tolulyticus Td-17 and Td-21), Lglutamate (no substrate except for L-malate has been tested for Azoarcus evansii pF6 according to the literature); no growth on D( + )mannose, $\mathrm{L}(+)$-arabinose, maltitol, $N$-acetyl-D-glucosamine, D-gluconate, caprate; ${ }^{*}$ no growth on $\mathrm{D}(+)$-galactose, $\mathrm{D}(+)$-trehalose, $\mathrm{L}(+)$-sorbose, $\alpha$-D $(+)$-melibiose, $\mathrm{D}(+)$-raffinose, $\alpha$-lactose, lactulose, 1- $O$-methyl- $\beta$-galactopyranoside, 1- $O$-methyl- $\alpha$-galactopyranoside, $\mathrm{D}(+)$-cellobiose, $\beta$-gentiobiose, 1 - $O$-methyl- $\beta$-D-glucopyranoside, $\mathrm{D}(-)$-ribose, $\mathrm{D}(+)$-xylose, $\alpha$-L-rhamnose, $\alpha$-L-fucose, $\mathrm{D}(+)$-arabitol, L(-)-arabitol, xylitol, dulcitol, D-tagatose, myo-inositol, D-sorbitol, adonitol, hydroxyquinoline- $\beta$-glucuronide, D-lyxose, erythritol, 1- $O$-methyl- $\alpha$-D-glucopyranoside, 3- $O$-methyl-glucopyranose, D-saccharate, mucate, D-glucuronate, D-galacturonate, 2-keto-D-gluconate, 5-keto-D-gluconate, 3-phenylpropionate, caprylate, 4-aminobutyrate, DL- $\alpha$-amino- $n$-valerate, trigonelline, putrescine, histamine, ethanolamine, D-glucosamine, tyrosine. a, positive for strain BS2-10, weak for strain OSP14-2; b, positive for strain BS2-10; c, positive for strain LFN91; d, negative for strain BS1-14; e, positive for strains BS2-10, OSP14-2 (Azoarcus indigens) and positive for strains OSB2-4, BS1-14 (Azovibrio restrictus); f, positive for strain BS19-5; g, negative for strain pF6; h, negative for strains VW35a and VW34c; i, positive for strain BS2-10; j, positive for strain BS1-14. 


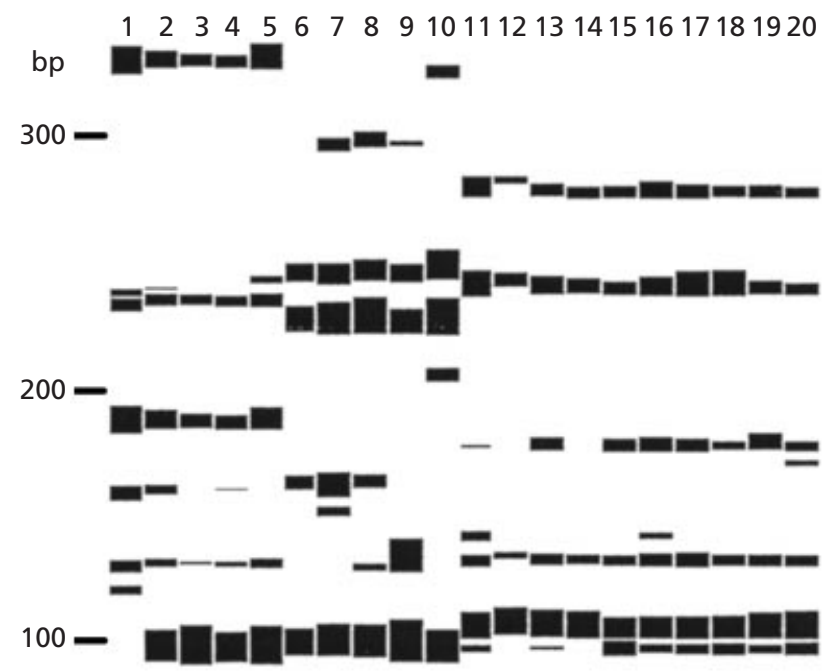

Fig. 2. Genomic fingerprints of Azoarcus spp. generated by tDNA-PCR. Amplification products were analysed on an ALFexpress automated sequencer, using the Fragment Manager program (Pharmacia). Lanes: 1-5, Azoarcus indigens strains VB32 ${ }^{\top}, \mathrm{VW} 34 \mathrm{c}, \mathrm{VW} 35 \mathrm{a}, \mathrm{BS2}-10$ and OSP14-2, respectively; 6-10, Azoarcus sensu lato sp. group $\mathrm{C}$ strains $\mathrm{S} 5 \mathrm{~b} 2^{\mathrm{T}}$, Ssa3, OSB2-4, BS1-14 and BS20-3, respectively; 11-20, Azoarcus sensu lato sp. group D strains 6a3 $3^{\top}, 6 a 2$, OO80-5, OSB4-5, OSP16-4, BS2-3, OM8A5, OSL52-5, OSP39 and OSC17, respectively. Positions of size markers are indicated on the left.

Azonexus) for Azoarcus sensu lato sp. groups C, D and $\mathrm{E}$, respectively. A neighbour-joining tree inference was carried out on a large set of sequence data containing all genera of the $\beta$-subclass of the Proteobacteria. It clustered the Rhodocyclus group and genera Azoarcus, Thauera and Zoogloea at a significant level $(89 \%)$ in bootstrap analysis (not shown). However, the internal nodes separating the Thauera, Zoogloea and Azoarcus clades were not well resolved (not shown), as we had observed previously (Hurek et al., 1997). Since the set of data were too large to carry out maximumlikelihood analysis with sufficient puzzling steps, an unrooted tree of the Rhodocyclus group was inferred with three different algorithms (maximum-likelihood, neighbour-joining and parsimony). The tree topology of the ML analysis is shown in Fig. 3, with confidence values for all three different algorithms given at the nodes when significant (larger than 50\%).

The following conclusions can be drawn.

(i) Azoarcus sensu lato is not monophyletic. It was divided from the Azoarcus sensu stricto clade by the Thauera clade in all three analyses (Fig. 3): the node separating the genera Thauera and Azoarcus sensu stricto from Azoarcus sensu lato and Zoogloea was well supported in maximum-likelihood and neighbourjoining analyses $(80 / 81 \%)$. On the other hand, the node grouping Azoarcus sensu lato (Azovibrio) and Zoogloea is well supported in parsimony analysis $(89 \%)$. None of our analyses placed the entire
Azoarcus group unambiguously in one clade. Therefore, Azoarcus sensu lato sp. groups C, D and E are unlikely to belong to the genus Azoarcus sensu stricto, as suggested previously (Hurek et al., 1997).

(ii) Azoarcus sensu lato sp. groups C, D and E represented different lineages, despite their exact phylogenetic relationships within the Rhodocyclus subgroup not being well resolved. The branch lengths and thus the phylogenetic distances for all three groups in maximum-likelihood and neighbour-joining analyses were similar to those of other genera such as Thauera or Rhodocyclus, indicating that groups C, D and E might have the rank of three different genera.

(iii) Azoarcus sensu stricto fell into two different clades. The analysis of phylogenetic relationships in the Azoarcus/Thauera subgroup was rendered difficult because the branching pattern at the Thauera/ Azoarcus node was unstable and most likely multifurcated. The resolution of phylogenetic analyses of $16 \mathrm{~S}$ rDNA in taxa closely related to each other is sometimes limited, for example in the genera previously collected in Rhizobium, the evolutionary relationships are not clear (Wang et al., 1998; Young \& Haukka, 1996). Despite this drawback, all named species and also strains of uncertain affiliation in the genus Thauera clustered in one clade, mostly with highly significant support levels (Fig. 3). This was also the case for most soil-borne species or strains of Azoarcus of uncertain affiliation, supporting the reliability of our analyses and their suitability to assign novel strains to known groups. Likewise, Azoarcus anaerobicus, whose phylogenetic position was not clear because tree inference had previously been carried out with only eight reference sequences (Springer et al., 1998) could be clearly localized in this clade (Fig. 3). Another isolate, $\mathrm{mXyN1}$ (Rabus \& Widdel, 1995), was apparently misnamed in the database as Azoarcus and was clearly a member of Thauera (Fig. 3). In contrast, none of the Azoarcus species containing plant-associated strains was located in the clade of soil-borne species in any type of analysis we carried out. Since the phylogenetic distances within these clades and Thauera were similar, both subgroups of Azoarcus sensu stricto might also deserve the rank of different genera in future.

\section{Morphological, nutritional and physiological features}

Strains within the different groups of Azoarcus sensu lato showed a similar cell and colony morphology with pronounced intergroup differences (Table 2). All were highly motile, slightly curved rods with one polar flagellum (Fig. 4e), but cells of Azoarcus sp. group D were smaller in width than, for example those of group C (Fig. 4a, b). Cell morphology underwent typical changes especially in semi-solid, $\mathrm{N}$-free medium which becomes alkaline after prolonged growth: in Azoarcus sp. group D, elongated cells of 4-5 $\mu \mathrm{m}$ with one helical winding occurred (Fig. 4a), very rarely with several windings, and a cell length of $8 \mu \mathrm{m}$ in late-stationary- 


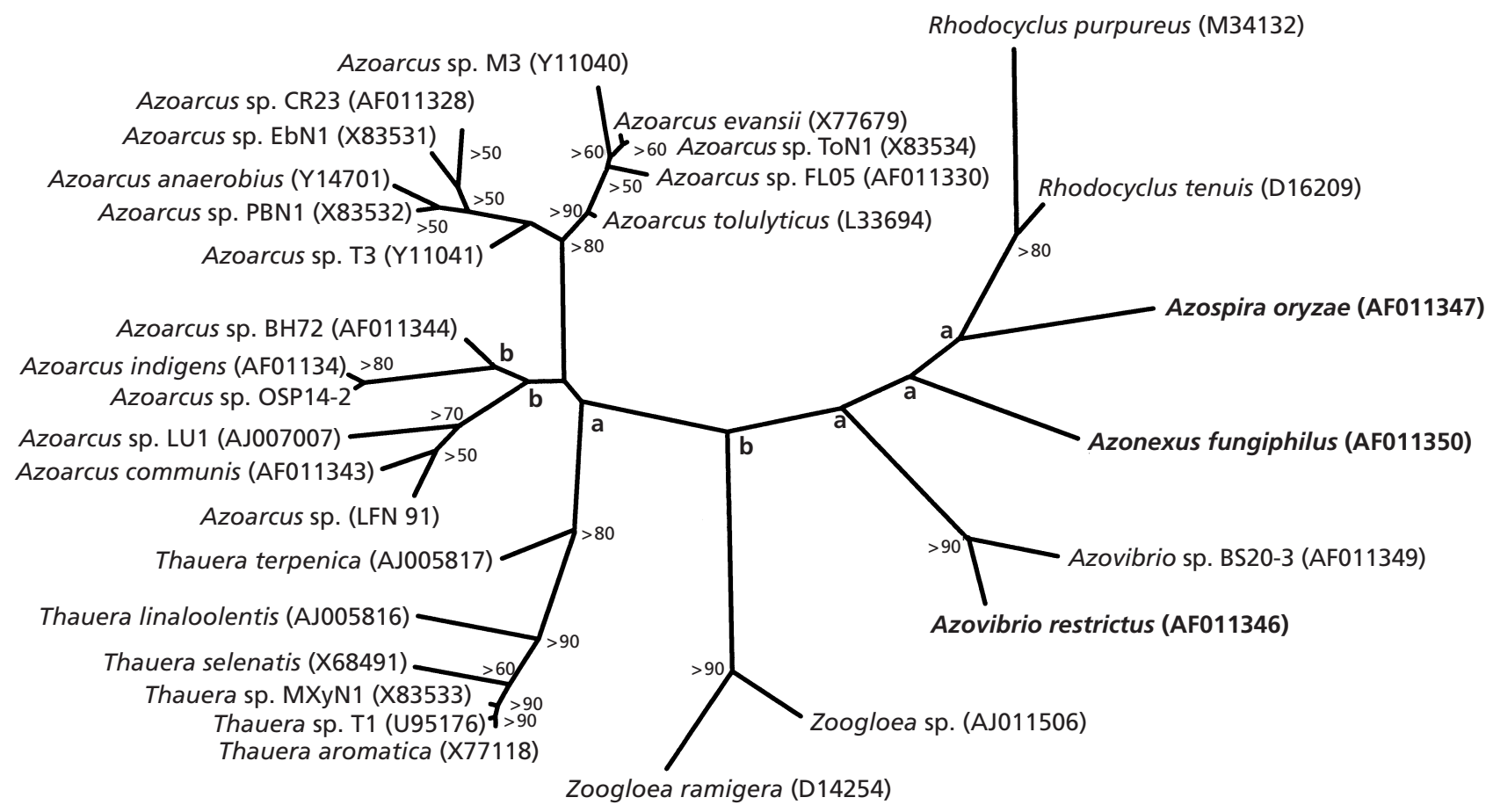

0.05

Fig. 3. Phylogenetic analysis of $16 \mathrm{~S}$ rDNA sequences (1338 positions) from the Rhodocyclus-Azoarcus subgroup of the $\beta$ subclass of the Proteobacteria. The genera Azovibrio, Azospira and Azonexus were formerly called Azoarcus sensu lato sp. group C, D and E, respectively. An unrooted maximum-likelihood quartet-puzzling tree based on 10000 puzzling steps is shown. The reliability of each internal branch is indicated by how often the corresponding cluster was found among 10000 intermediate trees expressed as a percentage. Maximum-likelihood branch lengths are proportional to the number of nucleic acid substitutions per site. The same set of sequences was also analysed by using the neighbour-joining algorithm or the parsimony algorithm with 100 bootstrap repetitions. Confidence values are given at nodes when all three analyses were giving values above $90 \%(>90), 80 \%(>80)$ and so on. a, Maximum-likelihood and neighbourjoining confidence values greater than $60 \%$, not significantly supported by parsimony; b, maximum-likelihood and neighbour-joining confidence values greater than $50 \%$, not significantly supported by parsimony. The differences in tree topology by parsimony are: Azospira and Azonexus branches interchanged, and Azovibrio and Zoogloea branches interchanged. GenBank accession numbers of $16 \mathrm{~S}$ rDNA sequences are shown in parentheses.

phase culture. Members of Azoarcus group E formed some large-loop-like, coiled, extremely elongated cells of up to $50 \mu \mathrm{m}$ in early-stationary-phase cultures (Fig. 4d), which sometimes appeared to fragment into halfmoon-shaped cells later (Fig. 4c). Both cell types were not observed for Azoarcus sp. group C (Fig. 4b). Strain BS20-3, which belongs to this group (Hurek et al., 1997) had an identical cell shape but did not share colony morphology, since it does not grow on agar plates in air due to obligate microaerophily.

The physiological and nutritional features of the different species or groups of Azoarcus sensu stricto and sensu lato are shown in Table 2. Tests for all strains (including one strain each of Azoarcus evansii and Azoarcus tolulyticus) were carried out under identical conditions. In carbon source utilization patterns, only few interstrain differences were observed within Azoarcus sp. group D and group E (Azospira and Azonexus), respectively. This indicated that they are phenotypically homogeneous groups despite the minor deviations in some electrophoretic protein patterns, which did not correlate with the small nutritional or physiological differences. This was also the case for Azoarcus sp. group C (Azovibrio), with the exception of strain BS20-3 that differed in cobalamine requirement and four of the carbon sources tested (Table 2). In addition, carbon utilization patterns were useful for differentiation of groups C, D and E from each other and from species of Azoarcus sensu stricto (Tables 2 and 3 ).

In Azoarcus sensu stricto, most of the tests carried out for the original genus description (Reinhold-Hurek et al., 1993) and in the present study have not been reported for members of the novel soil-borne species Azoarcus tolulyticus and Azoarcus evansii. Therefore, we tested two representative strains (Table 2). They differed considerably from the plant-associated species in colony morphology, especially lacking the yellowish pigment which was observed in the original genus description. Moreover, they grew on several carbo- 


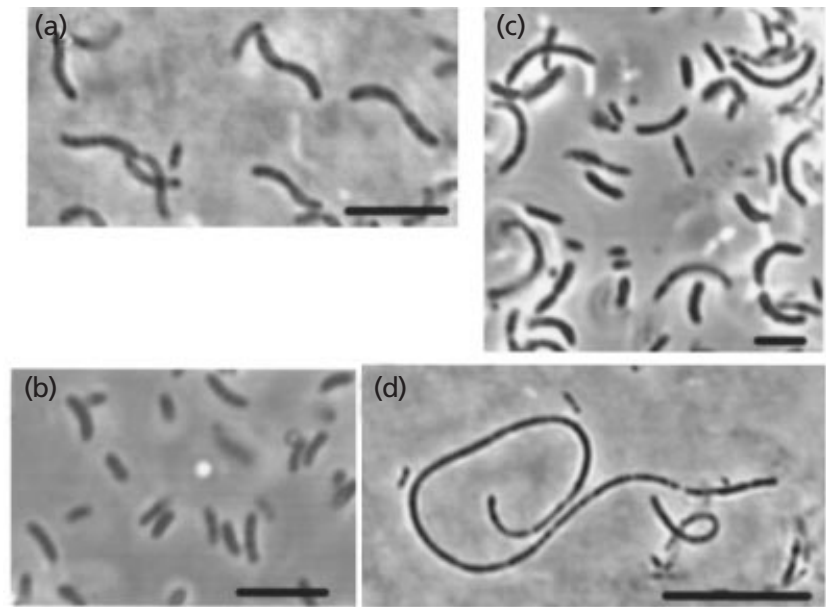

(e)

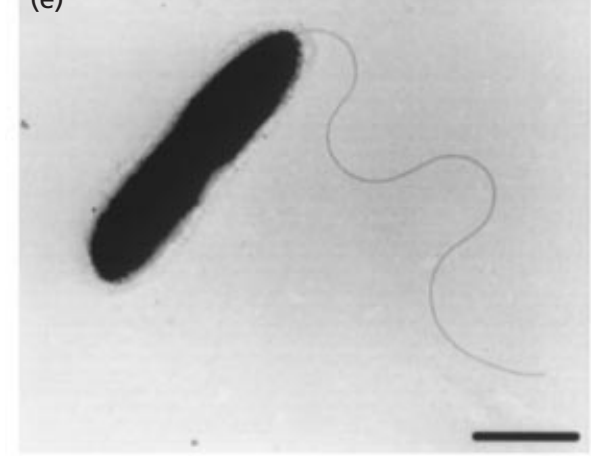

Fig. 4. Cell morphology of Azospira oryzae (a), Azovibrio restrictus (b, e) and Azonexus fungiphilus (c, d). Phase-contrast images of cells grown under $\mathrm{N}_{2}$ in semi-solid medium during exponential (b), stationary (d) and late-stationary growth phases $(a, c)$, or transmission electron micrograph after negative staining with phosphotungstate (e). Bars, $5 \mu \mathrm{m}(a-c)$, $10 \mu \mathrm{m}(\mathrm{d})$ or $1 \mu \mathrm{m}(\mathrm{e})$.

hydrates, again deviating from the original description of Azoarcus (Reinhold-Hurek et al., 1993).

The majority of the tests have not been carried out on the growing number of isolates from soil or sediment which have been reported to belong to Azoarcus (Harder et al., 1998; Hess et al., 1998; Rabus \& Widdel, 1995; Rhee et al., 1997; Springer et al., 1998; Van Schie \& Young, 1998), and for many strains it is not clear whether they fix nitrogen (Harder et al., 1998; Rabus \& Widdel, 1995; Rhee et al., 1997; Van Schie \& Young, 1998), a key feature in the original description of Azoarcus (Reinhold-Hurek et al., 1993). Therefore, it is difficult to draw conclusions about the phenotypic homogeneity of the genus at this point and all bacteria of this genus should be subjected to an identical set of tests in future.

\section{Conclusions}

Based on our polyphasic taxonomic studies, we propose to split the genus Azoarcus into four genera: Azoarcus (previously Azoarcus sensu stricto), contain- ing the validly described species Azoarcus communis, Azoarcus indigens, Azoarcus tolulyticus, Azoarcus evansii and Azoarcus anaerobicus, as well as strain BH72 differing at the species level (Reinhold-Hurek et al., 1993) and additional strains belonging to both Azoarcus 16S rDNA clusters (Fig. 3). Three groups of Azoarcus sensu lato sp., C, D and E, deserve the rank of three separate genera with one species in each, Azovibrio restrictus gen. nov., sp. nov., Azospira oryzae gen. nov., sp. nov. and Azonexus fungiphilus gen. nov., sp. nov., respectively. The following results support this proposal. (i) Strains can be assigned to these three groups by electrophoretic protein patterns, genomic fingerprints, cellular fatty acid compositions (Reinhold-Hurek et al., 1993), morphological features and carbon source utilization patterns; genotypic and phenotypic homogeneity within these groups suggest that strains belong to the same species (except for strain BS20-3 in the genus Azovibrio, which might represent a separate species but was not analysed in more detail because only one strain is available at present). (ii) Previous DNA-DNA hybridization studies (Reinhold-Hurek et al., 1993) have shown that these groups differ at least at the species level from each other and other Azoarcus species. (iii) Phylogenetic analyses of $16 \mathrm{~S}$ rDNA sequences using three different algorithms showed that Azoarcus sensu lato is not consistently monophyletic. Groups C, D and E form three lineages located between the Azoarcus/ Thauera and the Rhodocyclus clusters. (iv) Phylogenetic distances between groups $\mathrm{C}, \mathrm{D}$ and $\mathrm{E}$ are as large as between other genera, such as Rhodocyclus and group D, or Thauera and Azoarcus sensu stricto (Fig. 3). Accordingly, the percentage sequence similarity between them is only $93-94 \%$, values which also separate other proteobacterial genera from each other, e.g. Thauera/Azoarcus (Hurek et al., 1997), Telluria/ Duganella (Hiraishi et al., 1997) or Mesorhizobium/ Phyllobacterium (Jarvis et al., 1997). (v) The new genera can be differentiated from each other and from other related bacteria by phenotypic features (Table 3).

The remaining genus, Azoarcus, consists of at least two different $16 \mathrm{~S}$ rDNA clades, one of them containing a variety of isolates from soil and sediment which appear to differ considerably from the originally described, plant-associated species. To decide whether these soilborne strains deserve the rank of a separate genus, more detailed comparative phenotypic studies under standardized conditions will be necessary.

The species delineation within the genus Azoarcus is supported by DNA-DNA homology studies for the named species Azoarcus communis, Azoarcus indigens and the unnamed species represented by strain $\mathrm{BH} 72$ (Reinhold-Hurek et al., 1993). Azoarcus anaerobicus has a maximal $16 \mathrm{~S}$ rDNA identity of $97 \cdot 1 \%$ to other described species (Springer et al., 1998), a value which can be regarded as sufficiently low to allow description of a new species (Stackebrandt \& Goebel, 1994). According to this criterion, Azoarcus tolulyticus is 
Table 3. Differential characteristics of the genera Azoarcus, Azovibrio, Azospira, Azonexus and morphologically similar diazotrophs of the Proteobacteria

Data from this study and from Gillis \& Reinhold-Hurek (1994), Gillis et al. (1989) and Baldani et al. (1996). +, Positive for all strains; -, negative for all strains; D, differs among species; $d, 11-89 \%$ of strains are positive; ND, not determined.

\begin{tabular}{|c|c|c|c|c|c|c|c|c|}
\hline Character & Azoarcus & Azovibrio & Azospira & Azonexus & Herbaspirillum & $\begin{array}{c}\text { Burkholderia } \\
\text { vietnamensis }\end{array}$ & Azospirillum & $\begin{array}{c}\text { Acetobacter } \\
\text { diazotrophicus }\end{array}$ \\
\hline Subclass & $\beta$ & $\beta$ & $\beta$ & $\beta$ & $\beta$ & $\beta$ & $\alpha$ & $\alpha$ \\
\hline Cells curved & + & + & + & + & + & - & - & - \\
\hline Cell width $(\mu \mathrm{m})$ & $0 \cdot 4-1 \cdot 0$ & $0 \cdot 6-0 \cdot 8$ & $0 \cdot 4-0 \cdot 6$ & $0 \cdot 6-0 \cdot 8$ & $0 \cdot 6-0 \cdot 7$ & $0 \cdot 3-0 \cdot 8$ & $0 \cdot 8-1 \cdot 4$ & $0 \cdot 7-0 \cdot 9$ \\
\hline Colony colour* & Yellowish to beige & Beige & Pinkish translucent & Ochreous & Cream & Cream & Pinkish opaque & Brown \\
\hline Fermentative & - & - & - & - & - & - & D & + \\
\hline Growth on sugars & $\mathrm{D}^{\dagger}$ & - & - & - & + & + & + & + \\
\hline Requirement for cobalamine & - & - & - & + & - & - & - & - \\
\hline \multicolumn{9}{|l|}{ Growth on: } \\
\hline$n$-Butylamine & + & - & - & - & $\mathrm{D}$ & - & ND & ND \\
\hline 3-Hydroxybenzoate & + & - & - & - & + & + & ND & ND \\
\hline L-Phenylalanine & $+\ddagger$ & - & - & - & - & + & ND & ND \\
\hline Glutarate & $+\S$ & - & - & - & - & + & ND & ND \\
\hline 2-Oxoglutarate & $\mathrm{D}$ & - & + & + & + & d & $\mathrm{D}$ & ND \\
\hline n-Caproate & D & - & + & - & - & + & ND & ND \\
\hline Propionate & D & + & + & - & + & + & + & ND \\
\hline L-Proline & $\mathrm{D}$ & - & - & + & + & + & + & + \\
\hline
\end{tabular}

* On VM ethanol agar or nutrient agar.

$\dagger$ Positive for soil-borne species, negative for grass-associated species.

$\ddagger$ Negative for Azoarcus sp. BH72.

$\S$ Negative for Azoarcus indigens.

sufficiently different from the plant-associated species (Zhou et al., 1995). However, Azoarcus evansii has a 16S rRNA identity as high as $99.4 \%$ to some strains of Azoarcus tolulyticus (Anders et al., 1995) and DNADNA homology studies have not been carried out.

\section{Description of Azovibrio gen. nov.}

Azovibrio (A.zo'vi.bri.o. Fr. n. azote nitrogen; L. v. vibrare move rapidly to and fro, vibrate; M.L. masc. n. Azovibrio nitrogen-fixing organism which vibrates; combination of French/Latin by analogy with $\mathrm{Azo}-$ spirillum).

Formerly Azoarcus sp. group C. Gram-negative, nonspore-forming, slightly curved rods; cells range from 0.6 to $0.8 \mu \mathrm{m}$ in width and from 1.5 to $3.6 \mu \mathrm{m}$ in length; elongated cells occur very rarely in stationary, alkalinized cultures. Highly motile with a corkscrew-like motion by means of a single polar flagellum. Microaerophilic growth as veil-like pellicles which move up to the surface in semi-solid $\mathrm{N}$-free media. Strictly respiratory type of metabolism with oxygen or nitrate as terminal electron acceptor; however, strictly microaerobic growth may occur. Chemorganoheterotrophic. Oxidase-positive. Catalase-weak. No dissimilatory nitrate reductase. Growth factor requirement varies. Capable of growth in atmospheric nitrogen $\left(\mathrm{N}_{2}\right)$ and reduction of acetylene to ethylene. Growth is restricted to a few carbon sources, like salts of organic acids such as L-malate, DL-lactate, succinate, fumarate, acetate, propionate and ethanol, and amino acids such as L-glutamate. No growth occurs on most other organic acids and amino acids, nor on any mono-or disaccharides (Table 2). Grow well at $37^{\circ} \mathrm{C}$.

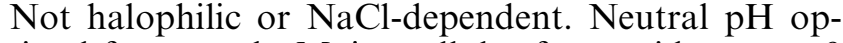
timal for growth. Major cellular fatty acids are cis-9 $16: 1,16: 0,18: 1,14: 0$ and $3-\mathrm{OH}-10: 1 . \mathrm{G}+\mathrm{C}$ content of DNA is $64-65 \mathrm{~mol} \%$. Member of the $\beta$-subclass of the Proteobacteria. Characteristics differentiating them from other diazotrophs given in Table 2 and 3. Type species is Azovibrio restrictus.

\section{Description of Azovibrio restrictus gen. nov., sp. nov.}

Azovibrio restrictus (re'stric.tus. L. adv. restrictus limited, restricted, referring to the restricted spectrum of carbon sources used for growth).

On VM ethanol medium, colonies are opaque beige, smooth, convex with an entire margin; on Congo red medium, colonies are orange-red, shining with otherwise similar characteristics. Grows weakly in presence of $2 \% \mathrm{NaCl}$. Most strains grow at $40{ }^{\circ} \mathrm{C}$. No requirement for cobalamine. In addition to those described for the genus, can use L-aspartate as sole carbon source, but not isovalerate or 3-hydroxybutyrate. Source is surface-sterilized roots of gramineae such as Kallar grass [Leptochloa fusca (L.) Kunth] or rice (Oryza sativa), grown in the Punjab of Pakistan or Nepal, respectively, or resting stages (sclerotia) of a basidiomycete (Pakistan). Type strain, S5b2 ${ }^{\mathrm{T}}(=$ LMG $9099^{\mathrm{T}}$ ), has a $\mathrm{G}+\mathrm{C}$ content of $64.8 \mathrm{~mol} \%$ and was isolated from Kallar grass roots. It grows at $40{ }^{\circ} \mathrm{C}$ and on $\mathrm{D}(+)$-malate.

Another strain of this genus is BS20-3. Differs from Azovibrio restrictus by obligately microaerobic growth, thus colony growth is negligible. Requires cobalamine. L-Alanine, isovalerate, isobutyrate and 3-hydroxy- 
butyrate, but not L-aspartate, serve as sole carbon sources in addition to those mentioned in the genus description. Source: resting stages (sclerotia) of a basidiomycete (Pakistan).

\section{Description of Azospira gen. nov.}

Azospira (A.zo'spi.ra. Fr. n. azote nitrogen; L. fem. n. spira winding, turn; M.L. fem. n. Azospira nitrogenfixing spiral).

Formerly Azoarcus sp. group D. Gram-negative, nonspore-forming, curved rods; cells range from 0.4 to $0.6 \mu \mathrm{m}$ in width and from 1.1 to $2.5 \mu \mathrm{m}$ in length; elongated cells with one to several spiral windings of up to $8 \mu \mathrm{m}$ cell length occur rarely in late-stationaryphase, alkalinized, nitrogen-fixing cultures. Highly motile with a corkscrew-like motion by means of a single polar flagellum. Microaerophilic growth as veillike pellicles which move up to the surface in semi-solid $\mathrm{N}$-free media. Strictly respiratory type of metabolism with oxygen or nitrate as terminal electron acceptor. Chemorganoheterotrophic. Oxidase-positive. Catalase-positive. No dissimilatory nitrate reductase. Growth factor requirement varies. Capable of growth in atmospheric nitrogen $\left(\mathrm{N}_{2}\right)$ and reduction of acetylene to ethylene. Grow mostly on salts of organic acids, such as L-malate, DL-lactate, succinate, fumarate, acetate, 2-oxoglutarate, $n$-caproate and propionate, and on ethanol; no growth occurs on most amino acids, nor on any mono-or disaccharides (Table 2). Grow well at $37^{\circ} \mathrm{C}$. Not halophilic or NaCl-dependent: no growth at $2 \% \mathrm{NaCl}$. Neutral $\mathrm{pH}$ optimal for growth. Major cellular fatty acids are cis-9 16:1, 16:0, 18:1 and 3-OH-10:1. G+C content of DNA is 65-66 mol \%. Member of the $\beta$-subclass of the Proteobacteria. Characteristics differentiating them from other diazotrophs given in Table 2 and 3 . Type species is Azospira oryzae.

\section{Description of Azospira oryzae gen. nov., sp. nov.}

Azospira oryzae (o'ry.zae. L. fem. n. Oryza genus name of rice; L. gen. n. oryzae from rice, referring to its frequent occurrence in association with rice roots).

On VM ethanol medium, colonies are translucent, pinkish to salmon coloured, smooth, convex with an entire margin; on Congo red medium, colonies are translucent orange, shining with otherwise similar characteristics. In addition to those described for the genus, can use D-tartrate, isovalerate, 3-hydroxybutyrate, L-glutamate and L-aspartate as sole carbon source. Growth optimum at $40^{\circ} \mathrm{C}$. Source is surfacesterilized roots of gramineae such as Kallar grass [Leptochloa fusca (L.) Kunth] or several species of rice (Oryza), grown in the Punjab of Pakistan or Nepal, Philippines and Italy, respectively, or resting stages (sclerotia) of a basidiomycete (Pakistan). Type strain is $6 \mathrm{a} 3^{\mathrm{T}}\left(=\mathrm{LMG} 9096^{\mathrm{T}}\right)$, which has a $\mathrm{G}+\mathrm{C}$ content of $65.2 \mathrm{~mol} \%$ and was isolated from Kallar grass. It has no requirement for cobalamine.

\section{Description of Azonexus gen. nov.}

Azonexus (A.zo'nex.us. Fr. n. azote nitrogen; L. masc. n. nexus coil; M.L. masc. n. Azonexus nitrogen-fixing coil).

Formerly Azoarcus sp. group E. Gram-negative, nonspore-forming, slightly curved rods; cells range from 0.6 to $0.8 \mu \mathrm{m}$ in width and from 1.5 to $4.0 \mu \mathrm{m}$ in length; elongated straight to coiled cells of up to $50 \mu \mathrm{m}$ length occur in stationary-phase, alkalinized, nitrogen-fixing cultures. Highly motile with a corkscrew-like motion by means of a single polar flagellum. Microaerophilic growth as veil-like pellicles which move up to the surface in semi-solid $\mathrm{N}$-free media. Strictly respiratory type of metabolism with oxygen as the terminal electron acceptor. Chemorganoheterotrophic. Oxidase-positive. Catalase-positive. Growth requirement for cobalamine. Capable of growth in atmospheric nitrogen $\left(\mathrm{N}_{2}\right)$ and reduction of acetylene to ethylene. Grow mostly on salts of organic acids, such as Lmalate, DL-lactate, succinate, fumarate, 2-oxoglutarate and acetate, and on ethanol; grows on only a few amino acids such as L-proline and none of the tested mono-or disaccharides serve as sole carbon sources (Table 2). Grows well at $37^{\circ} \mathrm{C}$; can grow at $40^{\circ} \mathrm{C}$. Not halophilic or $\mathrm{NaCl}$-dependent, but growth occurs at $2 \% \mathrm{NaCl}$. Neutral $\mathrm{pH}$ optimal for growth. Member of the $\beta$-subclass of the Proteobacteria. Characteristics differentiating them from other diazotrophs given in Table 2 and 3. Type species is Azonexus fungiphilus.

\section{Description of Azonexus fungiphilus, gen. nov., sp. nov.}

Azonexus fungiphilus (fun.gi'phil.us. M.L. masc. n. fungi mushroom, fungi; Gr. adj. philos loving; M.L. masc. adj. fungiphilus loving mushrooms or fungi, referring to its source of isolation).

On VM ethanol medium, colonies are opaque ochreous, smooth, convex with an entire margin; on Congo red medium, colonies are dark red, shining with otherwise similar characteristics. In addition to those described for the genus, can use 3-hydroxybutyrate, L-glutamate and L-aspartate as sole carbon source. Source: resting stages (black sclerotia) of a basidiomycete related to Ustilago found in a rice field in Pakistan. Type strain is BS5-8 ${ }^{\mathrm{T}}$ (= LMG $19178^{\mathrm{T}}$ ).

\section{ACKNOWLEDGEMENTS}

We thank James M. Tiedje, Michigan State University, and Georg Fuchs, Universität Freiburg, Germany, for the gift of strains, and also Christiane Staubitz and Christina Neumann (both MPI) for assistance in some nutritional and biochemical tests.

\section{REFERENCES}

Anders, A., Kämpfer, P., Ludwig, W. \& Fuchs, G. (1995). Taxonomic position of aromatic-degrading denitrifying pseudomonad strains K 172 and KB 740 and their description as new 
members of the genera Thauera, as Thauera aromatica sp. nov., and Azoarcus, as Azoarcus evansii sp. nov., respectively, members of the beta subclass of the Proteobacteria. Int J Syst Bacteriol 45, 327-333.

Baldani, J. I., Pot, B., Kirchhof, G. \& 8 other authors (1996). Emended description of Herbaspirillum: inclusion of [Pseudomonas] rubrisubalbicans, a mild plant pathogen, as Herbaspirillum rubrisubalbicans comb. nov., and classification of a group of clinical isolates (EF Group 1) as Herbaspirillum species 3. Int J Syst Bacteriol 46, 802-810.

Boddey, R. M. (1995). Biological nitrogen fixation in sugar cane: a key to energetically viable biofuel production. Crit Rev Plant Sci 14, 263-279.

Cacarez, E. A. R. (1982). Improved medium for isolation of Azospirillum spp. Appl Environ Microbiol 44, 990-991.

Engelhard, M., Horek, T. \& Reinhold-Hurek, B. (2000). Preferential occurrence of diazotrophic endophytes, Azoarcus spp., in wild rice species and land races of Oryza sativa in comparison with modern races. Environ Microbiol 2, in press.

Felsenstein, J. (1993). PHYLIP (Phylogeny Inference Package) version 3.5.1. Seattle: Department of Genetics, University of Washington, USA.

Fries, M., Zhou, J., Chee-Sanford, J. \& Tiedje, J. M. (1994). Isolation, characterization, and distribution of denitrifying toluene degraders from a variety of habitats. Appl Environ Microbiol 60, 2802-2810.

Gillis, M., Kersters, K., Hoste, B., Janssens, D., Kroppenstedt, R. M., Stephan, M. P., Teixeira, K. R. S., Doebereiner, J. \& De Ley, J. (1989). Acetobacter diazotrophicus sp. nov., a nitrogenfixing acetic acid bacterium associated with sugar cane. Int $J$ Syst Bacteriol 39, 361-364.

Harder, J. (1997). Anaerobic degradation of cyclohexane-1,2diol by a new Azoarcus species. Arch Microbiol 168, 199-204.

Hess, A., Zarda, B., Hahn, D., Haner, A., Stax, D., Hohener, P. \& Zeyer, J. (1998). In situ analysis of denitrifying toluene- and $\mathrm{m}-$ xylene-degrading bacteria in a diesel fuel-contaminated laboratory aquifer column. Appl Environ Microbiol 63, 2136-2141.

Hiraishi, A., Shin, J. K. \& Sugiyama, J. (1997). Proposal to reclassify Zoogloea ramigera IAM 12670 (P. R. Dugan 155) as Duganella zoogloeoides gen. nov., sp. nov. Int J Syst Bacteriol 47, 1249-1252.

Hurek, T. \& Reinhold-Hurek, B. (1995). Identification of grassassociated and toluene-degrading diazotrophs, Azoarcus spp., by analyses of partial $16 \mathrm{~S}$ ribosomal DNA sequences. Appl Environ Microbiol 61, 2257-2261.

Hurek, T., Burggraf, S., Woese, C. R. \& Reinhold-Hurek, B. (1993). $16 \mathrm{~S}$ rRNA-targeted polymerase chain reaction and oligonucleotide hybridization to screen for Azoarcus spp., grassassociated diazotrophs. Appl Environ Microbiol 59, 3816-3824.

Hurek, T., Van Montagu, M., Kellenberger, E. \& Reinhold-Hurek, B. (1995). Induction of complex intracytoplasmic membranes related to nitrogen fixation in Azoarcus sp. BH72. Mol Microbiol 18, 225-236.

Hurek, T., Wagner, B. \& Reinhold-Hurek, B. (1997). Identification of $\mathrm{N}_{2}$-fixing plant- and fungus-associated Azoarcus species by PCR-based genomic fingerprints. Appl Environ Microbiol 63, 4331-4339.

Jarvis, B. D. W., Van Berkum, P., Chen, W. X., Nour, S. M., Fernandez, M. P., Cleyet-Marel, J. C. \& Gillis, M. (1997). Transfer of Rhizobium huakuil, Rhizobium ciceri, Rhizobium mediterraneum, and Rhizobium tianshanense to Mesorhizobium gen. nov. Int J Syst Bacteriol 47, 895-898.
Kersters, K. (1985). Numerical methods in the classification of bacteria by protein electrophoresis. In Computer-assisted Bacterial Systematics, pp. 337-368. Edited by M. Goodfellow, D. Jones \& F. G. Priest. London: Academic Press.

Kiredjian, M., Holmes, B., Kersters, K., Guilvout, I. \& De Ley, J. (1986). Alcaligenes piechaudii, a new species from human clinical specimens and the environment. Int $J$ Syst Bacteriol 36, 286-287.

Laguerre, G., Bossand, B. \& Bardin, R. (1987). Free-living dinitrogen-fixing bacteria isolated from petroleum refinery oily sludge. Appl Environ Microbiol 53, 1674-1678.

Rabus, R. \& Widdel, F. (1995). Anaerobic degradation of ethylbenzene and other aromatic hydrocarbons by new denitrifying bacteria. Arch Microbiol 163, 96-103.

Reinhold, B., Hurek, T. \& Fendrik, I. (1985). Strain-specific chemotaxis of Azospirillum spp. J Bacteriol 162, 190-195.

Reinhold, B., Hurek, T., Niemann, E.-G. \& Fendrik, I. (1986). Close association of Azospirillum and diazotrophic rods with different root zones of Kallar grass. Appl Environ Microbiol 52, 520-526.

Reinhold-Hurek, B. \& Hurek, T. (1998). Life in grasses: diazotrophic endophytes. Trends Microbiol 6, 139-144.

Reinhold-Hurek, B., Hurek, T., Gillis, M., Hoste, B., Vancanneyt, M., Kersters, K. \& De Ley, J. (1993). Azoarcus gen. nov., nitrogenfixing proteobacteria associated with roots of Kallar grass (Leptochloa fusca (L.) Kunth) and description of two species Azoarcus indigens sp. nov. and Azoarcus communis sp. nov. Int $J$ Syst Bacteriol 43, 574-584.

Rhee, S. K., Lee, G. M., Yoon, J. H., Park, Y. H., Bae, H. S. \& Lee, S. T. (1997). Anaerobic and aerobic degradation of pyridine by a newly isolated denitrifying bacterium. Appl Environ Microbiol 63, 2578-2585.

Springer, N., Ludwig, W., Philipp, B. \& Schink, B. (1998). Azoarcus anaerobicus sp. nov., a resorcinol-degrading, strictly anaerobic, denitrifying bacterium. Int J Syst Bacteriol 48, 953-956.

Stackebrandt, E. \& Goebel, B. M. (1994). Taxonomic note: a place for DNA-DNA reassociation and 16S rRNA sequence analysis in the present species definition in bacteriology. Int $J$ Syst Bacteriol 44, 846-849.

Tamura, K. \& Nei, M. (1993). Estimation of the number of nucleotide substitutions in the control region of mitochondrial DNA in humans and chimpanzees. Mol Biol Evol 10, 512-526.

Van de Peer, Y. \& De Wachter, R. (1994). TREECON for Windows: a software package for the construction and drawing of evolutionary trees for the Microsoft Windows environment. CABIOS 10, 569-570.

Van Schie, P. M. \& Young, L. Y. (1998). Isolation and characterization of phenol-degrading denitrifying bacteria. Appl Environ Microbiol 64, 2432-2438.

Wang, E. T., van Berkum, P., Beyene, D., Sui, X. H., Dorado, O., Chen, W. X. \& Martinez-Romero, E. (1998). Rhizobium huatlense sp. nov., a symbiont of Sesbania herbacea that has a close phylogenetic relationship with Rhizobium galagae. Int J Syst Bacteriol 48, 687-699.

Young, J. P. W. \& Haukka, K. E. (1996). Diversity and phylogeny of rhizobia. New Phytol 133, 87-94.

Zhou, J., Fries, M. R., Chee-Sanford, J. C. \& Tiedje, J. M. (1995). Phylogenetic analyses of a new group of denitrifiers capable of anaerobic growth on toluene and description of Azoarcus tolulyticus sp. nov. Int J Syst Bacteriol 45, 500-506. 